\title{
Combinatorially Selected Peptides for Protection of Soybean Against Phakopsora pachyrhizi
}

\author{
Zhiwei D. Fang, James J. Marois, Gary Stacey, James E. Schoelz, James T. English, and Francis J. Schmidt
}

First, third, fourth, and fifth authors: Division of Plant Sciences, 108 Waters Hall, and sixth author: Division of Biochemistry, 117 Schweitzer Hall, University of Missouri, Columbia 65211; and second author: Plant Pathology Department, North Florida Research and Education Center, University of Florida, 3925 Hwy 71, Marianna 32446.

Accepted for publication 27 May 2010.

\begin{abstract}
Fang, Z. D., Marois, J. J., Stacey, G., Schoelz, J. E., English, J. T., and Schmidt, F. J. 2010. Combinatorially selected peptides for protection of soybean against Phakopsora pachyrhizi. Phytopathology 100:1111-1117.

Phakopsora pachyrhizi, the fungal pathogen that causes Asian soybean rust, has the potential to cause significant losses in soybean yield in many production regions of the United States. Germplasm with durable, singlegene resistance is lacking, and control of rust depends on timely application of fungicides. To assist the development of new modes of soybean resistance, we identified peptides from combinatorial phagedisplay peptide libraries that inhibit germ tube growth from urediniospores of $P$. pachyrhizi. Two peptides, $\mathrm{Sp} 2$ and $\mathrm{Sp} 39$, were identified that

inhibit germ tube development when displayed as fusions with the coat protein of M13 phage or as fusions with maize cytokinin oxidase/ dehydrogenase (ZmCKX1). In either display format, the inhibitory effect of the peptides on germ tube growth was concentration dependent. In addition, when peptides $\mathrm{Sp} 2$ or $\mathrm{Sp} 39$ in either format were mixed with urediniospores and inoculated to soybean leaves with an 8-h wetness period, rust lesion development was reduced. Peptides $\mathrm{Sp} 2$ and $\mathrm{Sp} 39$, displayed on $\mathrm{ZmCKX1}$, were found to interact with a 20-kDa protein derived from germinated urediniospores. Incorporating peptides that inhibit pathogen development and pathogenesis into breeding programs may contribute to the development of soybean cultivars with improved, durable rust tolerance.
\end{abstract}

Invasive plant pathogens present a constant challenge to the agricultural economy and food security in the United States. The impact of invasive pathogens in terms of crop loss and management costs is estimated at $\$ 23.5$ billion annually (25). Among the most significant invasive pathogens are fungi and oomycetes. Rossman (29) noted the difficulty of rapidly detecting invasive fungal species hidden within plant tissues that are distributed within germplasm sold commercially or exchanged from points of introduction. Rossman (29) also noted the extreme diversity of fungi, a lack of comprehensive taxonomic description, and consequent difficulty of rapid identification, diagnosis, and mitigation. Additional potential limitations to rapid response against invasive pathogens include a lack of durable, single-gene resistance in existing plant germplasm collections and a lack of Environmental Protection Agency (EPA)-registered fungicides, with concomitant delays in their application.

Fang et al. (7) suggested a strategy for rapid response to invasive species, based on the selection and deployment of combinatorially derived peptides that bind to infectious structures of a pathogen and inhibit growth and pathogenesis. To demonstrate the feasibility of this strategy, tomato hairy roots were transformed to express a peptide selected for its ability to induce encystment of Phytophthora capsici zoospores (2). The selected peptide, when expressed in roots as a fusion with maize cytokinin oxidase/ dehydrogenase (ZmZKX1), a secretable protein, induced premature encystment that disrupted zoospore chemotaxis and reduced

Corresponding authors: F. J. Schmidt; E-mail address: schmidtf@missouri.edu and J. T. English; E-mail-address: englishj@missouri.edu

* The $\boldsymbol{e}$-Xtra logo stands for "electronic extra" and indicates that the online version contains a supplementary table.

doi:10.1094/PHYTO-12-09-0365

(C) 2010 The American Phytopathological Society root infection. The discovery of peptides that induce zoospore encystment was independent of any prior information concerning specific attributes of the population of $P$. capsici's molecular targets (e.g., receptors).

We have investigated the potential of combinatorially derived peptides to inhibit infections initiated by the emerging invasive plant pathogen Phakopsora pachyrhizi Syd. \& P. Syd., the causal agent of Asian soybean rust. This pathogen was first reported in Asia in the early 20th century $(9,33)$ and has progressively spread worldwide. In regions where environmental conditions are conducive to rust development, crop losses of $>80 \%$ have been reported (19). P. pachyrhizi was introduced into the United States in 2004, most likely in association with Hurricane Ivan (30). It is now endemic in many soybean-growing regions along the Gulf coast and spreads to northern growing regions annually. Despite extensive searches, no durable single-gene resistance to Asian soybean rust has been discovered (8).

$P$. pachyrhizi typically produces only one type of infective spore, the urediniospore. A urediniospore that lands on the surface of a soybean leaf germinates to produce a germ tube that, in turn, produces an appressorium and penetration hypha. As is typical for biotrophic pathogens, further colonization of tissues occurs within the apoplast, with haustorium formation occurring intracellularly $(5,12,13)$.

The positioning of pathogen hyphae and haustoria within leaf tissues provides opportunities for contact with host-deployed, defensive transgenic factors that might interact with and interfere with normal function of fungal molecular targets. Because of the difficulty of selecting peptides against colonizing hyphae and haustoria, we have focused on elongating urediniospore germ tubes as a surrogate cellular target for peptide selection. Here, we report the discovery of peptides from combinatorial libraries that bind and inhibit $P$. pachyrhizi germ tube development, as well as confirmation of a potential protein target interaction. We conclude that combinatorial methods such as phage-peptide display allow 
the rapid isolation of effective inhibitory agents that could serve as precursors to enhanced soybean disease tolerance.

\section{MATERIALS AND METHODS}

Fungal materials and inoculum. Between 2006 and 2008, soybean leaves with rust pustules were collected from plants grown either in the field or in greenhouses at the North Florida Research and Education Center (University of Florida) located at Quincy, FL, and shipped to the Division of Plant Sciences (University of Missouri). There, the infected leaves were handled in the laboratory according to Animal and Plant Health Inspection Service (APHIS) regulations (APHIS permit 71988). Urediniospores were vacuumed from pustules on leaves using a Cyclone Surface Sampler (Burkard Mfg. Co. Ltd., Rickmansworth, England). These spores were used for initial evaluation of the inhibitory potential of affinity-selected, phage-display peptide clones.

Once soybean rust appeared in southeastern Missouri in 2008, a population of urediniospores was collected from all $P$. pachyrhizi pustules of a single soybean leaf using a Cyclone Surface Sampler. This urediniospore population, MOS-2008, was adjusted to a density of $10^{5}$ spores $/ \mathrm{ml}$ of water and misted onto 1- to 2-month-old soybean plants in a lighted growth chamber maintained under secure conditions as defined by the Missouri Department of Agriculture. Plants were maintained with a 12-h cycle of light and darkness at 18 to $20^{\circ} \mathrm{C}$. A Honeywell QuickSteam humidifier (Honeywell International, Inc., Morristown, NJ) was placed in the chamber to maintain relative humidity $(\mathrm{RH})>90 \%$. These inoculated plants served as a stock source of $P$. pachyrhizi urediniospores.

To produce inoculum for germination and plant infection studies, MOS-2008 urediniospores were vacuumed from leaves of stock plants using a Cyclone Surface Sampler, suspended in water, and misted onto detached soybean leaves contained in sealed plastic bags. After $15 \mathrm{~h}$ of incubation at $25^{\circ} \mathrm{C}$, inoculated leaves were removed from the bags, gently blotted dry, and transferred to $15-\mathrm{cm}$ petri plates containing $1 \%$ water agar. Leaves in petri plates were placed in a growth chamber (model MTR30; Conviron; Winnipeg, Manitoba, Canada) and maintained at $22^{\circ} \mathrm{C}$ and $90 \%$ RH with a 12-h cycle of light and darkness (cool white fluorescence lighting; $160 \mathrm{~W}$ ). Urediniospores were collected from leaves after 14 days incubation for use in experiments.

Selection of phage-display peptides with affinity for germinating $\boldsymbol{P}$. pachyrhizi urediniospores. The phage-display library, Ph.D.-12 (New England BioLabs Inc., Ipswich, MA), was used to develop the peptide-affinity selection protocol. The library consisted of random 12-mer peptides fused to five copies of a minor coat protein (pIII) of M13 phage and expressed at the N-terminus. The concentration of the original library was $1.5 \times 10^{13}$ virions $\mathrm{ml}^{-1}$, equivalent to 55 copies of each random peptide sequence per $10 \mu \mathrm{l}$ of the phage suspension.

Before affinity selection, the Ph.D.-12 library was amplified, purified twice by polyethylene glycol (PEG) precipitation, and resuspended in water to a concentration of $2.5 \times 10^{14}$ virions $\mathrm{ml}^{-1}$. In the affinity-selection procedure, one million urediniospores collected from soybean leaves in Florida were incubated in $1 \mathrm{ml}$ of water for $2.5 \mathrm{~h}$ at $22^{\circ} \mathrm{C}$ to induce germination. In all, $\approx 75 \%$ of urediniospores had germinated by this time. In the first round of affinity selection, $2.0 \times 10^{12}$ bacterial transducing units (TU) of phage (36), equivalent to $3.7 \times 10^{13}$ virions and $1.5 \times 10^{4}$ copies of each peptide sequence from the amplified library, were added to the germinated urediniospores and incubated for an additional 30 min with gentle shaking. The germinated urediniospore-phage mixture was then centrifuged at $1,000 \times g$ for $1 \mathrm{~min}$ to separate the urediniospore-bound phage from nonbound phage. The urediniospore-phage pellet was resuspended in $1 \mathrm{ml}$ of water, shaken gently, and centrifuged. After 10 wash cycles, bound phages were eluted from urediniospores by the addition of $200 \mu \mathrm{l}$ of elution buffer $(0.1 \mathrm{~N}$ glycine- $\mathrm{HCl}$ and $1 \mathrm{~g}$ of bovine serum albumin per liter) at $\mathrm{pH} 2.2$ and incubated for $10 \mathrm{~min}$ at $25^{\circ} \mathrm{C}$. The resulting affinity-selected phage suspension was neutralized with $40 \mu \mathrm{l}$ of $1 \mathrm{M}$ Tris- $\mathrm{Cl}$ (pH 9.0), and the titer (TU) of an aliquot of the eluate was determined. The remaining phage were amplified by infecting starved cells of Escherichia coli ER2738 (32) and purified twice by PEG-precipitation before final suspension in water.

Phage selection was continued for a total of three affinitypurification and two amplification cycles to enrich the phage pool in favor of peptides with strong binding affinity for germinating urediniospores. In the second and third rounds of affinity selection, the procedure was followed as described above, with a modified phage input of $2.0 \times 10^{11}$ rather than $2.0 \times 10^{12}$ TU. Phage eluted from urediniospores in the third (final) round of affinity selection were used to infect $E$. coli ER2738 cells. These cells were plated on Luria-Bertani plates containing $50 \mathrm{mg}$ of isopropyl-thio-galactopyranoside and $40 \mathrm{mg}$ of Xgal per liter. Blue plaques, each containing a single phage clone, were randomly selected for analysis of phage-display peptide bioactivity.

In vitro inhibition of urediniospore germ tube growth by phage-display peptides. Representative, affinity-selected, phagedisplay peptide clones were initially assessed in vitro for the ability to inhibit urediniospore germ tube growth. In all, 250 phage clones, randomly chosen from the final selection round, were amplified by E. coli infection, twice purified using PEGprecipitation, and resuspended in sterile deionized water. Phage concentrations were calculated from UV absorbance measurements as virions per microliter (2).

A $25-\mu \mathrm{l}$ water droplet containing $\approx 300$ nongerminated urediniospores collected from soybean leaves in Florida was incubated on a microscope slide in the presence of a phage clone at a concentration equivalent to $10^{13}$ virions $\mathrm{ml}^{-1}$. After $8 \mathrm{~h}$ of incubation at $22^{\circ} \mathrm{C}$, urediniospore germination in the presence of each test clone was compared visually with germination in water alone. Urediniospores were visualized using an Olympus Stereo Zoom Microscope (model SZH; Olympus Optical Co., Ltd., Tokyo) at $\times 50$ magnification under transmitted light. Images of germinating urediniospores were captured in random microscope fields with a Spot Insight Color digital camera (Diagnostic Instruments, Inc., Sterling Heights, MI). Images were manipulated for viewing using Spot imaging software (version 4.0.3) set up with autoexposure to provide contrast of developing germ tubes against a green background. Comparative germination was assessed in three separate experiments. Phage clones that induced $>50 \%$ reduction in germ tube length (by visual estimation) compared with germ tube growth in water were evaluated in seven additional experiments.

The region of the phage genomes that encoded inserted 12-mer peptides was sequenced. Single-stranded DNA was isolated from the recombinant phage particles of each clone (32) and sequenced from the $3^{\prime}$ end on a Prism 377 automated sequencer (Applied Biosystems, Foster City, CA) at the University of Missouri DNA Core facility. Nucleotide sequences were then translated into predicted amino acid sequences.

Effect of phage-display peptide concentration on urediniospore germ tube growth in vitro. The bioactivities of two inhibitory phage-display peptide clones, M13-Sp2 and M13-Sp39, identified in initial assessments were estimated over a range of concentrations, including $0.5,1.0$, and $1.5 \times 10^{13}$ virions $\mathrm{ml}^{-1}$. As before, a $25-\mu 1$ water droplet containing $\approx 300$ urediniospores was incubated at $22^{\circ} \mathrm{C}$ (4) on a microscope slide in the presence of M13-Sp2 or M13-Sp39 at each concentration. Urediniospores in these and all subsequent experiments were derived from the Missouri population, MOS-2008. Control treatments included urediniospores incubated in either water or an equivalent concentration of phage from an unselected library. Urediniospore germ tube growth was visualized over time and quantified by image 
capture and analysis using MetaMorph software (version 6.2r6; Universal Imaging, Downington, PA). Germ tube length was measured using a line-scan function based on conversion of image pixels to length. Germ tube length was averaged from 50 randomly selected germinated urediniospores in each image and across four experimental replicates per treatment.

Inhibition of leaf infection by phage-display peptides. Young, fully expanded soybean leaves were excised from soybean plants (Williams 82) and placed on $1 \%$ water agar in petri dishes. Two 10- $\mu$ l droplets of each phage-urediniospore or control treatment, as described for in vitro assessments, were applied to the upper surface of a single leaf. Each droplet contained 50 MOS-2008 urediniospores mixed with either M13-Sp2 or M13Sp39 at a final concentration of $10^{13}$ virions $\mathrm{ml}^{-1}$. Droplet treatments were replicated eight times. Inoculated leaves were incubated for $8 \mathrm{~h}$, a wetness period sufficient to ensure infection (18). Droplets were then rinsed from leaves under running water for $5 \mathrm{~min}$, and the leaf surface was gently blotted dry. Leaves were transferred to Parafilm-sealed petri dishes and incubated in a growth chamber (model MTR30, Conviron) at $22^{\circ} \mathrm{C}$ and $90 \% \mathrm{RH}$ with a 12-h cycle of light and darkness (cool white fluorescence lighting; $160 \mathrm{~W}$ ). The percentage of inoculations that produced rust lesions was recorded at 3- to 4-day intervals for 27 days.

Protein scaffold-display peptide construction and expression in Pichia pastoris. A recombinant version of ZmCKX1 (21) was used as a scaffold for display of bioactive peptides Sp2 and Sp39, identified in initial phage-display peptide clone assessments. This scaffold was shown previously to effectively deliver inhibitory peptides in plant tissues (7). The nucleotide sequences for peptides Sp2 (MLESHAWPPRAI) and Sp39 (YNKPSFQDHSVI) were inserted individually at the $3^{\prime}$ end of the $\mathrm{ZmCKX} 1$ gene. A stop codon was located immediately after the peptide insertion site. The native $\mathrm{N}$-terminal signal of $\mathrm{ZmCKX} 1$ was replaced with the $\alpha$-factor propeptide sequence of Saccharomyces cerevisiae (31) to ensure efficient secretion of expressed ZmCKX1-peptide fusions from $P$. pastoris strain X33.

ZmCKX1-Sp2 and ZmCKX1-Sp39 constructs were ligated into the Pichia pastoris cytoplasmic expression vector, pPZIC $\alpha$ (Easy Select Pichia Expression Kit Version B; Invitrogen, Carlsbad, CA). Subsequent transformation and manipulations of $P$. pastoris X33 were performed according to kit instructions. Typically, transformed X33 colonies were selected on Difco yeast extractpeptone-dextrose sorbitol (YPDS) medium (Becton Dickinson, Sparks, MD) amended with zeocin at $100 \mu \mathrm{g} \mathrm{ml}^{-1}$. One confirmed transformed colony from each $\mathrm{ZmCKX1-peptide} \mathrm{construct} \mathrm{was}$ inoculated into buffered minimal glycerol (BMGY) medium (Invitrogen), grown overnight, resuspended in buffered minimal methanol (BMMH) medium (Invitrogen) containing 0.5\% (vol/vol) methanol, and grown at $30^{\circ} \mathrm{C}$ with vigorous aeration. Additional methanol was added $(0.5 \%, \mathrm{vol} / \mathrm{vol})$ at 24,48 , and $72 \mathrm{~h}$ postinoculation.

At harvest, culture medium was centrifuged and the supernatant was cleared by filtration through a $0.22-\mu \mathrm{m}$ Stericup filter (Millipore, Billerica, MA). Recovered medium was concentrated through a Millipore NMWL:30,000 ultrafiltration membrane, and the medium was exchanged with Tris-EDTA buffer $(10 \mathrm{mM}$ Tris$\mathrm{Cl}, 1 \mathrm{mM}$ EDTA) at $\mathrm{pH} 8.0$ in a stirred-cell filtration apparatus. Purification of protein to $>95 \%$ electrophoretic homogeneity was achieved by size-exclusion chromatography on Superose 12 (Amersham Pharmacia Biotech, Piscataway, NJ).

The purified medium containing ZmCKX1-peptide was then passed through an Amicon Ultra-15 filter (Ultracel-30K; Millipore) and concentrated to $750 \mu \mathrm{l}$ by centrifugation. Concentrated medium was exchanged four times with $15 \times$ volume of sterile, deionized water and reconcentrated. Finally, $750 \mu \mathrm{l}$ of medium was cleared by filtration through a $0.22-\mu \mathrm{m}$ syringe filter before assessment of protein concentration, enzyme activity, and bioactivity against Phakopsora pachyrhizi urediniospores.
Purified ZmCKX1-peptide activity was measured by a continuous dichloroindophenol (DCPIP) reduction assay $(1,15)$. In a microtiter well, $50 \mu \mathrm{l}$ of ZmCKX1-SP2 or ZmCKX1-Sp39 was combined with $200 \mu \mathrm{l}$ of reaction mixture consisting of $250 \mu \mathrm{M}$

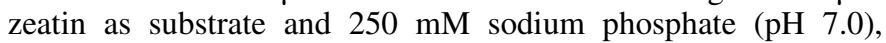
$125 \mu \mathrm{M}$ DCPIP, and $2.5 \mathrm{mM}$ EDTA. A control treatment for each ZmCKX1-peptide included the same reaction mixture but without zeatin. DCPIP reduction was measured at $590 \mathrm{~nm}$ at 10-s intervals for $10 \mathrm{~min}$ in a VersaMax (Molecular Devices, Sunnyvale, CA) microplate reader and quantified with Softmax Pro 4.3.1 software. Total protein in culture medium was assessed by Bradford assay.

In vitro and in planta inhibition of urediniospore germ tube growth and infection caused by ZmCKX1 peptides. Purified ZmCKX1-Sp2 and ZmCKX1-Sp39 peptides were assessed in vitro for the ability to inhibit urediniospore germ tube growth. A $25-\mu$ water droplet containing $\approx 300$ freshly harvested MOS-2008 urediniospores was incubated on a glass slide in the presence of either ZmCKX1-Sp2 or ZmCKX1-Sp39. Control treatments included urediniospores incubated in water or in the presence of ZmCKX1 alone. Germ tube growth was visualized over time and quantified by image capture and analysis as described previously.

Young, fully expanded leaves were excised from soybean plants (Williams 82) and used to assess infection inhibition caused by ZmCKX1 peptides. Two 10- $\mu$ l droplets of each ZmCKX1-peptide-urediniospore mixture or control treatment were applied to the upper surface of a single leaf. Each droplet contained 50 urediniospores mixed with either ZmCKX1-Sp2 or ZmCKX1Sp39 at a final concentration of $115 \mu \mathrm{M}$. Control treatments included urediniospores in water or mixed with $115 \mu \mathrm{M}$ ZmCKX1. Droplet treatments were replicated four times.

Inoculated leaves were incubated for $8 \mathrm{~h}$ before rinsing away droplets and drying as described previously. Leaves were transferred to sealed petri dishes and incubated in a growth chamber at $22^{\circ} \mathrm{C}$ and $90 \% \mathrm{RH}$, under a 12-h cycle of light and darkness. The percentage of inoculations that produced rust lesions was recorded at 3- to 4-day intervals for 27 days.

Characterization of protein targets in germinating urediniospores. A far-western assay was used to identify $P$. pachyrhizi proteins that bind to peptides $(3,35)$. To prepare fungal proteins, MOS-2008 urediniospores were germinated and grown for $4 \mathrm{~h}$. Fungal tissues were ground in liquid nitrogen and suspended in phosphate buffer (pH. 6.5) containing 0.1 M mannitol and Tween20. Fungal debris was separated from soluble material by centrifugation, and the protein concentration of the soluble fraction was determined. Equal amounts of protein were loaded into the wells of an acrylamide gel, separated by sodium dodecyl sulfate polyacrylamide gel electrophoresis, and then transferred to polyvinylidene difluoride membrane. The membranes were incubated with a bait protein that consisted of the ZmCKX1 scaffold alone, ZmCKX1-Sp2, or ZmCKX1-Sp39. The unbound bait proteins were washed off of the blot and the blot was incubated with ZmCKX1 polyclonal antibody (1), followed by a second antibody, anti-rabbit immunoglobulin $\mathrm{G}$ conjugated to alkaline phosphatase (Promega Corp., Madison, WI).

\section{RESULTS}

Phage-display peptide selection and assessment of bioactivity. We isolated phage from an M13 phage-display library that displayed combinatorial peptides with affinity for germinated urediniospores. When we assessed the bioactivity of enriched phage populations derived from three rounds of selection, we found that 20 of 250 phage-display peptide clones, at $10^{13}$ virions $\mathrm{ml}^{-1}$, reduced urediniospore germ tube growth by $\geq 50 \%$ in at least one of three in vitro trials (Fig. 1). We sequenced these bioactive clones and found that they carried 11 unique inserted peptide sequences (Table 1). Each of the 11 peptide sequences was retested in phage-display format to determine its relative effective- 
ness as a germ tube inhibitor. Using field-collected urediniospores, phage-display peptide clones inhibited germ tube growth in $30-80 \%$ of the tests (Table 1). Variation in germ tube inhibition was not surprising given that the field populations of urediniospores used in these initial evaluations likely were heterogeneous in age and viability.

We hypothesized that the most consistently active phagedisplay peptides in our enriched population would be multiply represented among the 20 clones and, indeed, this was the case (Table 1). The five phage-display peptide clones ( $\mathrm{Sp} 2, \mathrm{Sp} 14$, Sp15, Sp18, and Sp39) that inhibited germling growth in $\geq 50 \%$ of 10 trials were represented in the active phage-display peptide population between two and four times. With one exception (peptide Sp59), clones that were least consistently effective at inhibiting germ tube growth were represented only once. None of the phage-display peptide clones that inhibited germling growth significantly inhibited the percentage of urediniospore germination.

Urediniospore germ tube growth in the presence of phagedisplay peptides or ZmCKX1-peptides. We further characterized the ability of M13-Sp2 and M13-Sp39, the two most consistently active phage-display peptides in initial screenings (Table 1), to inhibit germ tube growth. After $8 \mathrm{~h}$ of incubation, the average germ tube length in water was $482 \mu \mathrm{m}$. Both clones inhibited growth during this time period in a concentrationdependent fashion (Fig. 2). Compared with growth in water, the average length of urediniospore germ tubes was reduced by 62 to $64 \%$ in the presence of either phage-display peptide clone at a concentration of $5 \times 10^{12}$ virions $\mathrm{ml}^{-1}$. Germ tube inhibition increased with higher virion concentrations to a maximum of 97 and $82 \%$ for M13-Sp2 and M13-Sp39, respectively, at a concentration of $5 \times 10^{13}$ virions $\mathrm{ml}^{-1}$. Germ tube growth in the presence of the unselected phage-display peptide library was not inhibited compared with growth in water $(<1.5 \%)$, except at the highest concentration of $5 \times 10^{13}$ virions $\mathrm{ml}^{-1}$, where growth inhibition was $32 \%$.

When peptides Sp2 and Sp39 were fused to the C terminus of the scaffold protein, ZmCKX1, they also inhibited urediniospore germ tube growth in vitro in a concentration-dependent fashion (Fig. 3). In these experiments, after $8 \mathrm{~h}$ of incubation, the average germ tube length in water was $438 \mu \mathrm{m}$. Compared with water, significant reductions in germ tube growth were detected at ZmCKX1-peptide concentrations of $\geq 58 \mu \mathrm{M}$. At $58 \mu \mathrm{M}$ ZmCKX1-Sp2 and ZmCKX1-Sp39, the average length of urediniospore germ tubes was reduced by 52 and $36 \%$, respectively. At the highest concentration of $230 \mu \mathrm{M}$ ZmCKX1-Sp2 or ZmCKX1Sp39, germ tube growth was decreased by 94 and $91 \%$, respectively. Germ tube growth in the presence of $\mathrm{ZmCKX} 1$ alone was inhibited $<10 \%$ at all concentrations except $230 \mu \mathrm{M}$, where $26 \%$ growth inhibition was detected.

Inhibition of $P$. pachyrhizi leaf infection by phage-display peptides or ZmCKX1-peptides. Peptides Sp2 and Sp39, when displayed on phage or as fusions with ZmCKX1, inhibited rust lesion development on soybean leaves inoculated with uredinio- spores (Fig. 4). Fifty urediniospores in $10 \mu \mathrm{l}$ of water inoculated to leaf surfaces and incubated for $8 \mathrm{~h}$ before drying produced visible lesions after 7 days of additional incubation (Fig. 5). An average of $\approx 40 \%$ of these inoculations produced lesions by that time. In comparison, only 7 and $12 \%$ of the urediniospore inoculations produced lesions when phage-display peptides M13Sp2 and M13-Sp39, respectively, were added to the inoculum. By

TABLE 1. Sequences of bioactive phage-display peptides that reduced germ tube growth of Phakopsora pachyrhizi urediniospores ${ }^{\text {a }}$

\begin{tabular}{llcc}
\hline Peptide & Amino-acid sequence & $\begin{array}{c}\text { No. of phage- } \\
\text { peptide clones } \\
\text { recovered }\end{array}$ & $\begin{array}{c}\text { Frequency of germ } \\
\text { tube inhibition } \\
\text { over 10 trials }\end{array}$ \\
\hline Sp2 & MLESHAWPPRAI & 3 & 8 \\
Sp5 & YISPLPNAATIS & 1 & 3 \\
Sp6 & TFDRHILDTRGS & 1 & 3 \\
Sp8 & STVASLGKPTKI & 1 & 4 \\
Sp14 & ASTIGNLMPGHS & 2 & 5 \\
Sp15 & FDPHEPTNTRSP & 2 & 6 \\
Sp18 & LTKEPATGRAML & 4 & 6 \\
Sp39 & YNKPSFQDHSVI & 2 & 7 \\
Sp51 & DHIRISTSYKSP & 1 & 3 \\
Sp59 & TPTRSLDSPHNM & 2 & 3 \\
Sp61 & DRFTSDLRAPDS & 1 & 3 \\
\hline
\end{tabular}

${ }^{a}$ Phage-display peptide clones were recovered from three affinity-selection rounds against germinated urediniospores.

${ }^{\mathrm{b}}$ Inhibition was defined as $\geq 50 \%$ germ tube inhibition after $8 \mathrm{~h}$ of incubation at $25^{\circ} \mathrm{C}$.

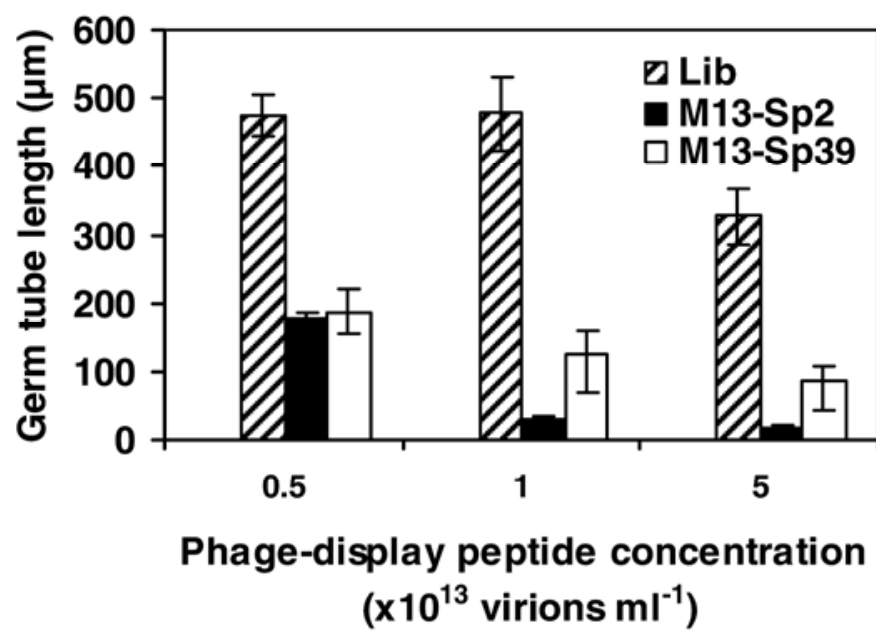

Fig. 2. Germ tube elongation of Phakopsora pachyrhizi urediniospores in relation to concentration of phage-display peptides M13-Sp2 and M13-Sp39 or in the presence of the unselected phage-display peptide library (Lib). Measurements of germ tube elongation were made after $8 \mathrm{~h}$ of incubation. Mean germ tube length in water was $481.5 \pm 46 \mu \mathrm{m}$. Bars indicate standard error of the mean $(n=4)$.
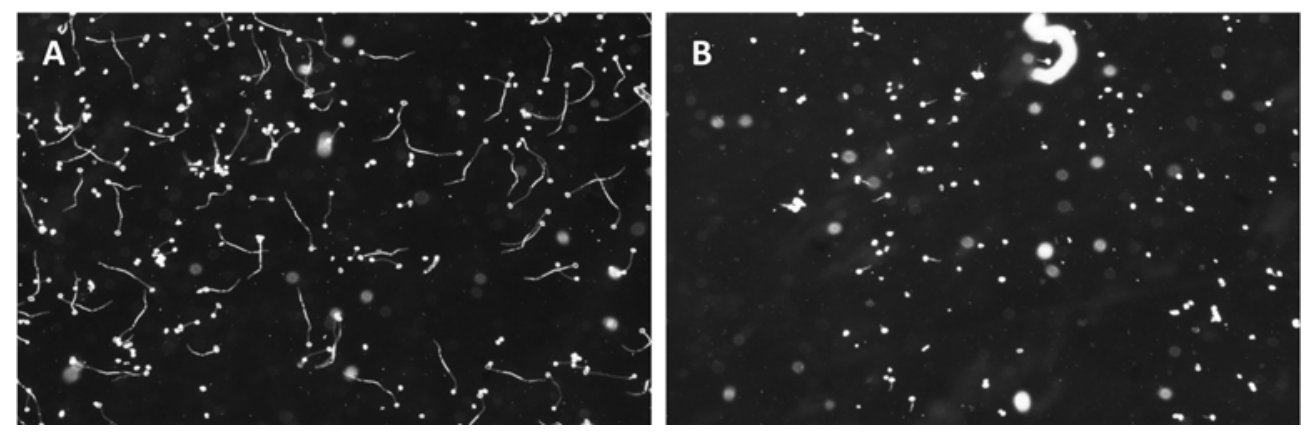

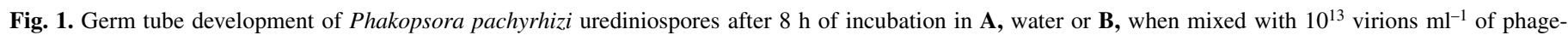
display peptide clone M13-Sp2. 
13 days after inoculation, an average of $82 \%$ of inoculations with urediniospores in water produced visible lesions, whereas lesion formation was reduced to 44 and $49 \%$ by M13-Sp2 or M13-Sp39, respectively. Although all inoculations with urediniospores in water produced lesions by 24 days, fewer than $75 \%$ of inoculations in the presence of either peptide ever produced lesions.

We noted similar reductions in lesion formation on soybean leaves inoculated with urediniospores mixed with scaffold peptides (Fig. 6). Although close to $50 \%$ of urediniospores inoculated to leaves in water had produced lesions after 7 days of incubation, lesion formation was reduced to 13 and $16 \%$ by the ZmCKX1-Sp2 and ZmCKX1-SP39 preparations, respectively. By day 24 , whereas a maximum of $74 \%$ of inoculations in the presence of scaffold peptides produced lesions, all urediniospores inoculated in water-produced lesions. The results indicate that the peptides were growth inhibitory but not fungicidal, an observation consistent with the in vitro activity of the peptides fused to either carrier phage or to ZmCKX1 (Figs. 2 and 3).

Detection of a protein target for Peptides Sp2 and Sp39. Scaffold-display peptides ZmCKX1-Sp2 and ZMCKX1-Sp39 specifically interacted with a fungal protein $\approx 20 \mathrm{kDa}$ in size (Fig. 7). Significantly, this protein was absent in the blot probed with the ZMCKX1 scaffold, indicating that the Sp-2 and Sp-39

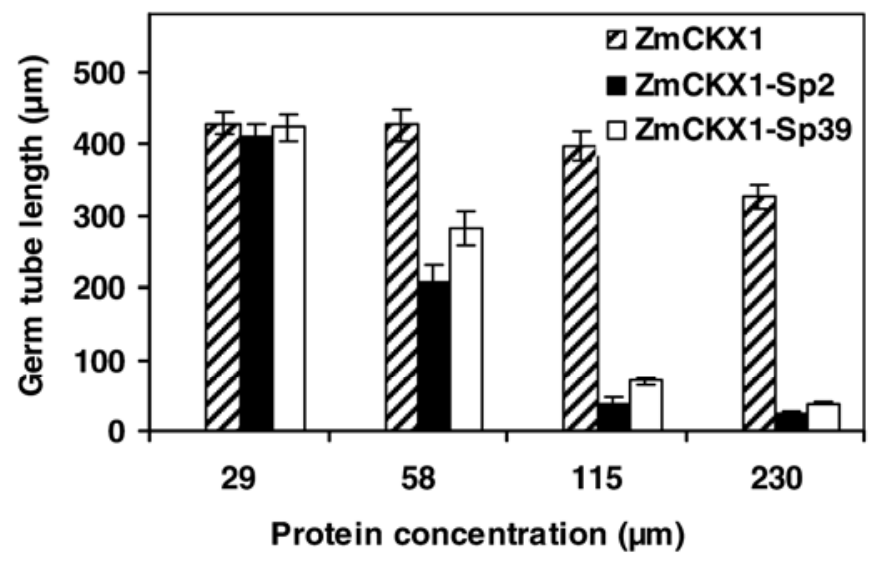

Fig. 3. Germ tube elongation of Phakopsora pachyrhizi urediniospores in relation to concentration of ZmCKX1 scaffold-display peptides ZmCKX1-Sp2 and ZmCKX1-Sp39 or ZmCKX1 without peptide insert. Measurements of germ tube elongation were made after $8 \mathrm{~h}$ of incubation. Mean germ tube length in water was $438.0 \pm 21 \mu \mathrm{m}$. Bars indicate standard error of the mean $(n=4)$.

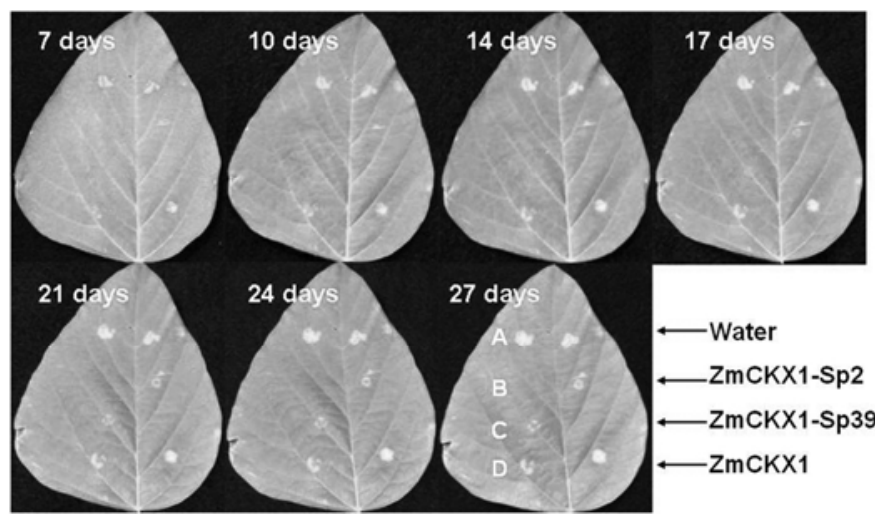

Fig. 4. Time-course development of rust lesions after inoculation of soybean leaves with 50 Phakopsora pachyrhizi urediniospores mixed with $10 \mu \mathrm{l}$ of $115 \mu \mathrm{M}$ scaffold-display peptides ZmCKX1-Sp2 and ZmCKX1-Sp39, $115 \mu \mathrm{M}$ ZmCKX1 without peptide insert, or water. Two replicate inoculations of each treatment were made per leaf. Leaf wetness was maintained for $8 \mathrm{~h}$ before blotting dry and subsequent incubation for 27 days. peptides were responsible for its detection. Because both the Sp-2 and Sp-39 peptides appeared to detect the same $20-\mathrm{kDa}$ protein, it indicates that these peptides either target the same sequence or target different sequences on the same protein.

\section{DISCUSSION}

P. pachyrhizi, the causative agent of Asian soybean rust, exemplifies the challenges presented by invasive and emerging plant pathogens in that, when this organism was introduced to the United States, no sustainable single-gene resistance was available in host germplasm collections (8). Consequently, the major treatment option remains timely application of fungicides $(19,22)$. Asian soybean rust is an ongoing problem because $P$. pachyrhizi is now endemic in the southern United States $(11,26,27)$, from

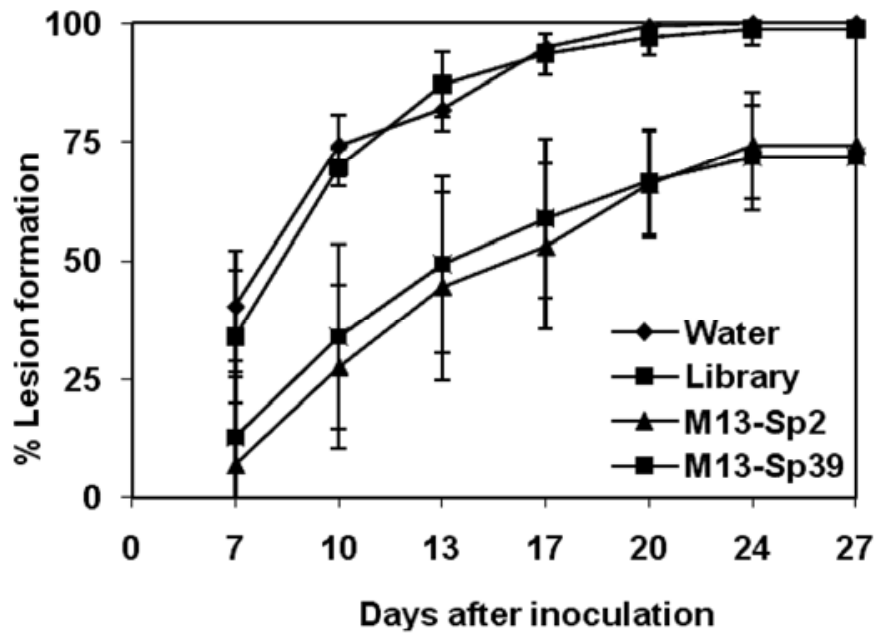

Fig. 5. Influence of phage-display peptides on rust lesion formation after leaf inoculation with Phakopsora pachyrhizi urediniospores. Leaves were inoculated with 50 urediniospores mixed with $10 \mu \mathrm{l}$ of phage-display peptides M13Sp2 and M13-Sp39 at $10^{13}$ virions $\mathrm{ml}^{-1}$, the unselected phage-display peptide library, or water. Leaf wetness was maintained for $8 \mathrm{~h}$ before blotting dry. Bars indicate standard error of the mean $(n=8)$.

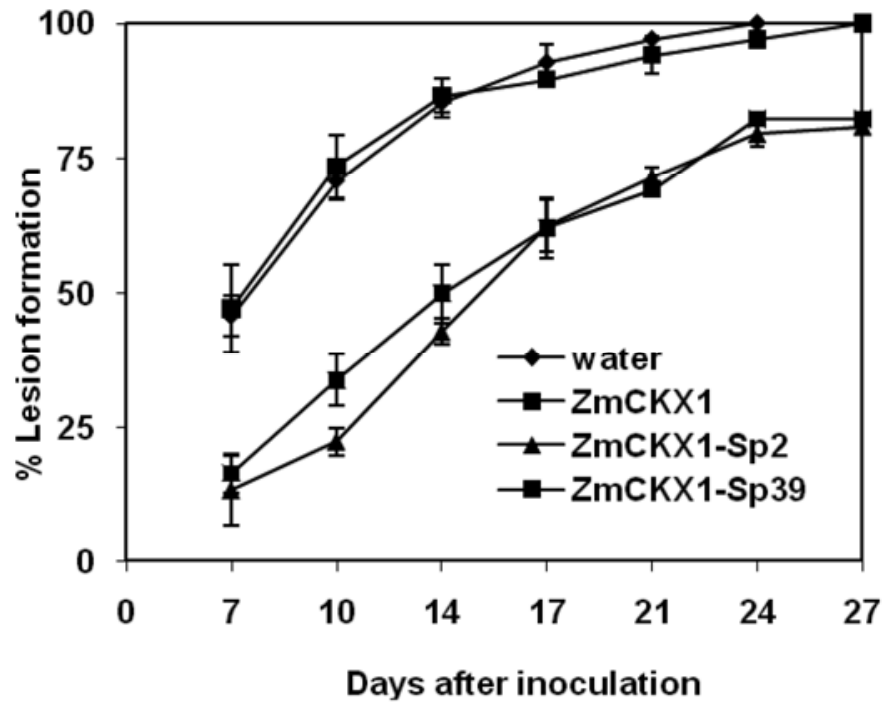

Fig. 6. Influence of scaffold-display peptides on rust lesion formation after inoculation with Phakopsora pachyrhizi urediniospores. Leaves were inoculated with 50 urediniospores mixed with $10 \mu \mathrm{l}$ of $115 \mu \mathrm{M}$ scaffold-display peptides ZmCKX1-Sp2 and ZmCKX1-Sp39, $115 \mu \mathrm{M}$ ZmCKX1 without peptide insert, or water. Leaf wetness was maintained for $8 \mathrm{~h}$ before blotting dry. Bars indicate standard error of the mean $(n=8)$. 
which it is capable of dispersing annually with shifting weather patterns $(6,14)$. Although the impact of rust on soybean production nationally has been lower than initially feared, the establishment of $P$. pachyrhizi in the United States provides opportunities for the evolution of environmentally adapted and more virulent populations.

The lack of durable resistance in commercial soybean and related germplasm collections has created a need for alternative modes of protection against rust. Efforts in this regard have focused on elucidation of soybean gene expression patterns $(23,24,34)$ as well as metabolic and cell structural changes (16) brought about by pathogen infection, with the intent of identifying critical defense response components.

The data presented here suggest that a pharmacological approach for dealing with invasive pathogens such as $P$. pachyrhizi has utility. The approach is straightforward, including (i) identifying infectious stages of the pathogen, (ii) finding combinatorially derived peptides that bind to infectious structures and inhibit the pathogen's life cycle, and (iii) displaying one or more inhibitory peptides on a suitable carrier (scaffold) protein. The carrier-peptide constructs can then be introduced into transgenic plant lines and screened by conventional assessment methods. This approach roughly parallels the screening approach used in developing biopharmaceuticals for human medicine.

A pharmacological approach was successful despite complications due to the preparation of pathogen inoculum. Urediniospores could not be produced on artificial growth medium because of the obligate lifestyle of the pathogen. Therefore, we obtained infectious urediniospores of $P$. pachyrhizi from soybean leaves grown in the field or greenhouse in Florida or under growth chamber conditions in our laboratory. Infection of leaves in the field and greenhouse occurs asynchronously through the course of multiple cycles of pathogen reproduction and secondary infection. As a result, urediniospores produced in these environments were exposed to variable periods of fluctuating solar radiation and temperatures before being harvested for experiments. Previous studies established that the viability of urediniospores is affected significantly by each of these environmental factors $(10,17)$. Variation in spore viability, inherent to mixed-age spore populations, likely contributed to the phenotypic variability that
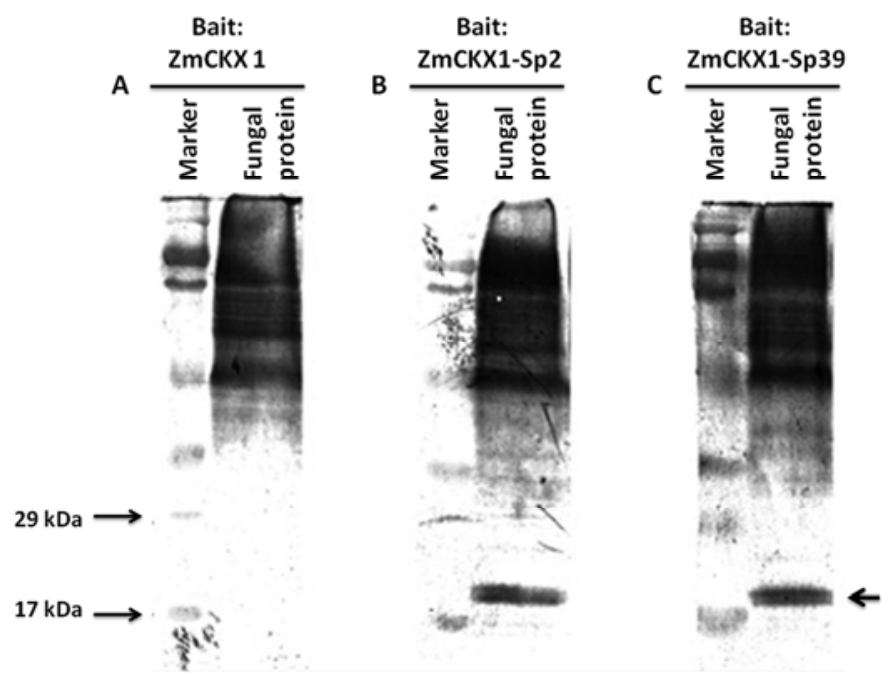

Fig. 7. Detection of a $20-\mathrm{kDa}$ Phakopsora pachyrhizi protein by peptides Sp-2 and Sp39 by far-western analysis. Protein extracted from germinated urediniospores was separated by sodium dodecyl sulfate polyacrylamide gel electrophoresis and transferred to a polyvinylidene difluoride membrane before incubation with either A, ZMCKX1; B, ZMCKX1-Sp2; or C, ZMCKX1-Sp39 protein, followed by successive treatments with $\mathrm{ZmCKX} 1$ antibody and antirabbit immunoglobulin $\mathrm{G}$ conjugated to alkaline phosphatase. Arrow on the right illustrates the $20-\mathrm{kDa}$ fungal protein band and arrows on the left indicate the sizes of protein standards. was observed in initial phage-display peptide-assessment experiments. In comparison, urediniospores produced in growth chambers after controlled, synchronous infection of leaves would be expected to be more uniform in behavior.

Of the peptides that showed promise for inhibition of germ tube growth, peptides $\mathrm{Sp} 2$ and $\mathrm{Sp} 39$ proved most effective over all experiments. These bioactive peptides inhibited urediniospore germ tube development in a concentration-dependent manner, and they showed similar efficacy in either phage- or scaffold-display formats. In phage-display format, $\mathrm{Sp} 2$ and $\mathrm{Sp} 39$ maximally inhibited germ tube elongation at $\approx 10^{13}$ virions $\mathrm{ml}^{-1}$. Because M13 phage virions display a copy of the Sp2 or Sp39 peptide on each of the five copies of the pIII coat protein, the effective peptide concentration was equivalent to $10 \mathrm{nM}$. In contrast, when $\mathrm{Sp} 2$ or Sp39 was displayed on the ZmCKX1 scaffold, maximum germ tube inhibition was achieved at $115 \mu \mathrm{M}$ concentration. The $\approx 100$-fold difference between effective phage- and scaffolddisplay peptide concentrations may reflect an avidity effect of multiple peptides being displayed on the phage virion. Alternatively, display of peptides on ZmCKX1 may favor different peptide conformations than display on the phage coat protein, also affecting affinity or activity of the peptides.

The inhibitory peptides acted as temporal inhibitors of urediniospore germination rather than as biocides. Soybean leaves inoculated with urediniospores mixed with peptides Sp2 and Sp39 in phage- or scaffold-display formats developed tan lesions that are characteristic of a susceptible response to infection $(8,20)$. However, the rate of appearance and final incidence of lesions in the presence of these peptides was notably lower than on leaves inoculated with urediniospores alone. This inhibition is highly significant, because the peptide effects were strongly evident in a one-time exposure of urediniospores to peptides on the surface of leaves. Based on our previous studies of ZmCKX1-peptide expression in tomato hairy roots (7), we hypothesize that sufficient peptide concentrations can be generated in the apoplast of soybean leaf tissues to inhibit $P$. pachyrhizi hyphal growth and haustorial development.

The application of combinatorial peptide selection against $P$. pachyrhizi provided a means for the rapid discovery of inhibitory peptides. The time from acquisition of $P$. pachyrhizi urediniospores to availability of DNA sequences for plant transformation was $\approx 1.5$ person-years, once necessary regulations were satisfied for working with the pathogen. In addition, this combinatorial, pharmacological approach may provide protective determinants limited in number only by the complexity of the phage display library, typically greater than one billion. Such diversity provides many opportunities for identifying peptides that target a range of pathogen functions such as germling growth in $P$. pachyrhizi, the premature encystment of zoospores as in P. capsici $(2,7)$, or some other function critical for pathogen development and pathogenesis.

The two inhibitory peptides Sp2 and Sp39 detected protein bands that had the same size in far-western blots. Further research will be necessary to determine whether the $\mathrm{Sp} 2$ and $\mathrm{Sp} 39$ peptides bind to the same $P$. pachyrhizi protein, as well as whether this protein may be a molecular target for inhibition essential for the infectious process. Nonetheless, far-western blots illustrated that peptides chosen for their capacity to inhibit a process such as germling growth can also bind to specific pathogen proteins; this presumably would be a prerequisite for determining the inhibitory mode of action of the peptides.

Both the speed of discovery and diversity of inhibitory peptides should be accelerated and enhanced as information on candidate molecular targets accumulate with continuing genomic and proteomic investigations $(23,24,28,34)$. Peptides can be readily selected by in vitro biopanning for their affinity to proteins critical for fungal growth and pathogenesis.

Selection of specific target-peptide interactions also allows the development of inhibitory peptides that are species specific, as we 
have observed in a previous study with Phytophthora capsici (2). This attribute is critical for addressing concerns of potential negative impacts on beneficial, symbiotic fungi and other microbes.

Finally, multiple peptides can be identified that have potentially different modes of inhibitory action, and these can be deployed in sequence because effectiveness might be lost in the presence of evolving pathogen populations. Incorporating one or more inhibitory peptides into breeding programs for partial resistance or yield stability (8) may assist the development of new soybean cultivars with enhanced, durable tolerance to rust.

We conclude that the use of combinatorially selected phagedisplay peptides as sources of pathogen-inhibitory determinants is a viable strategy to meet the challenges posed by Phakopsora pachyrhizi and other emerging pathogens.

\section{ACKNOWLEDGMENTS}

This work was supported by grants received from the Missouri Soybean Merchandising Council and the Illinois-Missouri Biotechnology Alliance.

\section{LITERATURE CITED}

1. Bilyeu, K. D., Cole, J. L., Laskey, J. G., Riekhof, W. R., Esparza, T. J., Kramer, M. D., and Morris, R. O. 2001. Molecular and biochemical characterization of a cytokinin oxidase from maize. Plant Physiol. 125:378-386.

2. Bishop-Hurley, S. L., Mounter, S. A., Laskey, J., Morris, R. O., Elder, J., Roop, P., Rouse, C., Schmidt, F. J., and English, J. T. 2002. Phagedisplayed peptides as developmental agonists for Phytophthora capsici zoospores. Appl. Environ. Microbiol. 68:3315-3320.

3. Bishop-Hurley, S. L., Schmidt, F. J., and Smith, A. L. 2005. Peptides selected for binding to a virulent strain of Haemophilus influenzae by phage display are bactericidal. Antimicrob. Agents Chemother. 49:29722978.

4. Bonde, M. R., Berner, D. K., Nester, S. E., and Frederick, R. D. 2007. Effects of temperature on urediniospore germination, germ tube growth, and initiation of infection in soybean by Phakopsora isolates. Phytopathology 97:997-1003.

5. Bonde, M. R., Melching, J. S., and Bromfield, K. R. 1976. Histology of the suscept-pathogen relationship between Glycine max and Phakopsora pachyrhizi, the cause of soybean rust. Phytopathology 66:1290-1294.

6. Christiano, R. S. C., and Scherm, H. 2007. Quantitative aspects of the spread of Asian soybean rust in the southeastern United States, 2005 to 2006. Phytopathology 97:1428-1433.

7. Fang, D. F., Laskey, J. G., Huang, S., Bilyeu, K. D., Morris, R. O., Schmidt, F. J., and English, J. T. 2006. Combinatorially selected defense peptides protect plant roots from pathogen infection. Proc. Natl. Acad. Sci. USA 103:18444-18449.

8. Hartman, G. L., Miles, M. R., and Frederick, R. D. 2005. Breeding for resistance to soybean rust. Plant Dis. 89:664-666.

9. Hennings, V. P. 1903. A few new Japanese Uredinaceae. Hedwigia 42:S107-108.

10. Isard, S. A., Dufault, N. S., Miles, M. R., Hartman, G. L., Russo, J. M., De Wolf, E. D., and Morel, E. 2006. The effect of solar irradiance on the mortality of Phakopsora pachyrhizi urediniospores. Plant Dis. 90:941945.

11. Jurick, W. M., II, Navaraez, D. F., Brennan, M. M., Harmon, C. L., Marois, J. J., Wright, D. L., and Harmon, P. F. 2008. Winter survival of the soybean rust pathogen, Phakopsora pachyrhizi, in Florida. Plant Dis. 92:1551-1558.

12. Koch, E., Ebrahim-Nesbat, F., and Hoppe, H. H. 1983. Light and electron microscopic studies on the development of soybean rust (Phakopsora pachyrhizi Syd.) in susceptible soybean leaves. Phytopathol. Z. 106:302320.

13. Koch, E., and Hoppe, H. H. 1988. Development of infection structures by the direct-penetrating soybean rust fungus (Phakopsora pachyrhizi Syd.) on artificial medium. J. Phytopathol. 122:232-244.
14. Krupa, S., Bowersox, V., Claybrooke, R., Barnes, R., Szabo, C. W., Harlin, K., and Kurle, J. 2006. Introduction of Asian soybean rust urediniospores into the Midwestern United States-a case study. Plant Dis. 90:1254-1259.

15. Laskey, F. G., Patterson, P., Bilyeu, D., and Morris, R. O. 2003. Rate enhancement of cytokinin oxidase/dehydrogenase using 2,6-dichlorophenol as an electron acceptor. Plant Growth Regul. 40:189-196.

16. Lygin, A. V., Li, S., Vittal, R., Widholm, J. M., Hartman, G. L., and Lozovaya, V. V. 2009. The importance of phenolic metabolism to limit the growth of Phakopsora pachyrhizi. Phytopathology 99:1412-1420.

17. Marchetti, M. A., Uecker, F. A., and Bromfield. 1976. The effects of temperature and dew period on germination and infection by uredospores of Phakopsora pachyrhizi. Phytopathology 66:461-463.

18. Melching, J. S., Dowler, W. M., Koogle, D. L., and Royer, M. H. 1989. Effects of duration, frequency, and temperature of leaf wetness periods on soybean rust. Plant Dis. 73:117-122.

19. Miles, M. R., Levy, C., Morel, W., Mueller, T., Steinlage, T., van Rij, N., Frederick, R. D., and Hartman, G. L. 2007. International fungicide efficacy trials for the management of soybean rust. Plant Dis. 91:14501458.

20. Miles, M. R., Pastor-Corrales, M. A., Hartman, G. L., and Frederick, R. D. 2007. Differential response of common bean cultivars to Phakopsora pachyrhizi. Plant Dis. 91:698-704.

21. Morris, R. O., Bilyeu, K. D., Laskey, J. G., and Cheikh, N. N. 1999. Isolation of a gene encoding a glycosylated cytokinin oxidase from maize. Biochem. Biophys. Res. Commun. 255:328-333.

22. Mueller, T. A., Miles, M. R., Morel, W., Marois, J. J., Wright, D. L., Kemerait, R. C., Levy, C., and Hartman, G. L. 2009. Effect of fungicide and timing of application on soybean rust severity and yield. Plant Dis. 93:243-248.

23. Panthee, D. R., Marois, J. J., Wright, D. L., Narváez, D., Yuan, J. S., and Stewart, C. N., Jr. 2009. Differential expression of genes in soybean in response to the causal agent of Asian soybean rust (Phakopsora pachyrhizi Sydow) is soybean growth stage-specific. Theor. Appl. Genet. 118:359-370.

24. Panthee, D. R., Yuan, J. S., Wright, D. L., Marois, J. J., Mailhot, D., and Stewart, C. N., Jr. 2007. Gene expression analysis in soybean in response to the causal agent of Asian soybean rust (Phakopsora pachyrhizi Sydow) in an early growth stage. Funct. Integr. Genomics 7:291-301.

25. Pimental, D., Zuniga, R., and Morrison, D. 2005. Update on the environmental and economic costs associated with alien-invasive species in the United States. Ecol. Econ. 52:273-288.

26. Pivonia, S., and Yang, X. B. 2004. Assessment of the potential year-round establishment of soybean rust throughout the world. Plant Dis. 88:523529.

27. Pivonia, S., and Yang, X. B. 2005. Assessment of epidemic potential of soybean rust in the United States. Plant Dis. 89:678-682.

28. Posada-Buitrago, M. L., and Frederick, R. D. 2005. Expressed sequence tag analysis of the soybean rust pathogen, Phakopsora pachyrhizi. Fungal Genet. Biol. 42:949-962.

29. Rossman, A. Y. 2009. The impact of invasive fungi on agricultural ecosystems in the United States. Biol. Invasions 11:7-101.

30. Schneider, R. W., Hollier, C. A., Whitam, H. K., Palm, M. E., McKenny, J. M., Hernández, J. R., Levy, L., and DeVries-Paterson, R. 2005. First report of soybean rust caused by Phakopsora pachyrhizi in the continental United States. Plant Dis. 89:774.

31. Scorer, C. A., Buckholz, R. G., Clare, J. J., and Romanos, M. A. 1993. The intracellular production and secretion of HIV-1 envelope protein in the methylotrophic yeast Pichia pastoris. Gene 136:111-119.

32. Smith, G. P., and Scott, J. K. 1993. Libraries of peptides and proteins displayed on filamentous phage. Methods Enzymol. 217:228-257.

33. Sydow, H., and Sydow, P. 1914. A contribution to knowledge of the parasitic fungi of the island of Formosa. Ann. Mycol. 12:105.

34. van de Mortel, M. Recknor, J. C., Graham, M. A., Nettleton, D., Dittman, J. D., Nelson, R. T., Godoy, C. V., Abdelnoor, R. V., Almeida, A. M. R., and Baum, T. 2007. Distinct biphasic mRNA changes in response to Asian soybean rust infection. Mol. Plant-Microbe Interact. 20:887-899.

35. Wu Y., Li Q., and Chen X. 2007. Detecting protein-protein interactions by far western blotting. Nat. Protocols 2:3278-3284.

36. Yu, J., and Smith, G. P. 1996. Affinity maturation of phage-displayed peptide ligands. Methods Enzymol. 267:3-27. 